\title{
Mentoring as a supportive pedagogy in theological training
}

\author{
Authors: \\ Nathan H. Chiroma \\ Anita Cloete ${ }^{1}$ \\ Affiliations: \\ ${ }^{1}$ Faculty of Theology, \\ Practical Theology, Youth \\ Work, Stellenbosch \\ University, South Africa \\ Correspondence to: \\ Nathan Chiroma \\ Email: \\ nhchiroma@sun.ac.za \\ Postal address: \\ Private Bag X1, Matieland \\ 7602 , Stellenbosch, \\ South Africa

\section{Dates:} \\ Received: 21 Apr. 2014 \\ Accepted: 03 Aug. 2014 \\ Published: 31 Mar. 2015 \\ How to cite this article: \\ Chiroma, N.H. \& Cloete, \\ A., 2015, 'Mentoring as \\ a supportive pedagogy \\ in theological training', \\ HTS Teologiese Studies/ \\ Theological Studies 71(3), \\ Art. \#2695, 8 pages. http:// \\ dx.doi.org/10.4102/hts. \\ v71i3.2695

\section{Copyright:} \\ (C) 2015. The Authors. \\ Licensee: AOSIS \\ OpenJournals. This work is \\ licensed under the Creative \\ Commons Attribution \\ License.
}

Read online:

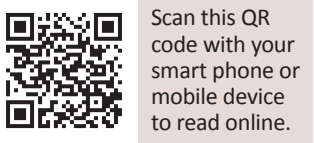

This article contends that theological training supported by effective mentoring can contribute to the shaping of theology students in terms of their spiritual growth, character development and ministry formation. It is further argued that mentoring as a supportive pedagogy needs to be an essential element of theological education. Subsequently, guidelines for making mentoring an effective pedagogy in theological training are proposed. A lot has been written about mentoring; however this article focuses on the use of mentoring as a supportive pedagogy in denominational seminaries as a means of fostering the holistic development of theology students.

\section{Introduction}

In recent years, interest has grown around the question of pedagogy in theological training (Ospino 2010; Delamarter, Alanís, Haitch, Hoffman, Jones, \& Strawn 2007; Farley 2005). The aim of theological education is to enhance the spiritual formation of theology students. Theological education aims at developing reflective Christian identity and practice, an informed and spiritually enriched access to biblical tradition, and empowering people for participating in the mission of God in this world. To fully accomplish the aim of theological education, classroom experience may not be enough; hence the call to incorporate mentoring as a supportive pedagogy that will promote the integration of classroom experience with spiritual formation of theology students. The article therefore examines the necessity of mentoring as a supportive pedagogy in theological education and how mentoring could assist the spiritual, character and ministry formation of theology students.

This article draws on of a doctoral thesis with the focus on critical evaluation of mentoring programs in three Evangelical Church Winning All (ECWA) seminaries. An empirical investigation was conducted in three major denominational seminaries in Nigeria. A qualitative approached was used, applying focus groups and individual interviews to obtain data. The empirical findings of this research reveal that mentoring plays an important role in the holistic development of seminary students especially in three areas, namely spiritual formation, character and ministry formation. It has shown that the integration of mentoring in theological seminaries is both biblically necessary and practically possible. Firstly, the concepts of mentoring, pedagogy and theological education are considered, followed by a discussion on the relationship between mentoring as a supportive pedagogy and theological training. Secondly, a set of guidelines for mentoring to be an effective supportive pedagogy in theological seminaries are discussed. In conclusion the importance of mentoring in theological training to promote spiritual, character (Christ-like) and ministry formation is underscored.

\section{Defining mentoring, pedagogy and theological education}

Due to wide-spread misunderstanding and debate surrounding the terms mentoring (Faure 2000), pedagogy and theological education (Cruises 2004), it is important to define these concepts and at the same time indicate how they will be used in this article.

\section{Mentoring}

Mentoring, for example, is a very broad and complex concept that includes many components and is therefore difficult to define. Despite the fact that there is not only one single definition for mentoring, it has been compared with other relational processes such as coaching, counselling, advising and teaching. According to Klasen and Clutterbuck (2002:172) and Chiroma (2012:78), when one analyses those comparisons further, mentoring does not represent only one of those relational processes, but in fact involves using all of them. 
The different formats of mentoring relationships are contested, particularly given their diverse underlying philosophies and purposes (Philip 2000:14). Traditionally, mentoring has been defined as an intrinsically personal process where an older person empowers a younger person. Galbraith (2001:89) defines mentoring as an activity by which older persons of higher rank, exceptional achievements and reputation instruct, counsel, guide and expedite the intellectual and/or career development of persons identified as protégés. Similarly, Merriam (1983:162) describes mentoring as 'a powerful emotional interaction between an older and younger person in a relationship in which the older mentor is trusted, loving, and experienced in the guidance of the younger'. Kram (1985:2) writes that the mentor 'supports, guides, and counsels a young adult as he or she accomplishes mastery of the adult world or the world of work'. Furthermore, Faure (2000:23) defines mentoring as 'a relationship that meets a development need, helps develop full potential, and benefits all partners; mentor, mentee and the organization'. Collins (2009) contends that:

$$
\begin{aligned}
& \text {... mentoring is a protected relationship in which learning and } \\
& \text { experimentation can transpire; potential skills can be developed, } \\
& \text { and in which results can be measured in terms of competencies } \\
& \text { gained. (p. 80) }
\end{aligned}
$$

According to Addington and Graves (2010:329), mentoring is a reciprocal relationship with an intentional agenda, designed to communicate explicit content along with life wisdom from one individual to another. It is clear from the above definitions that mentoring does not happen by accident. It is also evident that although mentoring is relationally based, it is more than just a meaningful friendship.

It seems as though the definitions of mentoring vary from structural to personal perspectives (Merriam 1983). Perhaps this explains why Cove, MacAdam and McGonigal (2007:87) describe mentoring as a voluminous concept with the potential for a variety of applications. Mentoring can therefore be seen as a developmental process which can occur both naturally and officially, to allow an individual to share his or her experience, knowledge and skills with another individual in order to benefit (mostly) the latter's personal and/or professional development. Masango (2011:1) stresses that mentoring is a process of support which aims to change behaviour in such a way that the protégé functions more fully and effectively.

While 'mentoring' is not found in English translations of the Bible, one can find many examples of the words that correspond with the meaning of mentoring as understood in this study. For example, the Greek term meno [enduring relationship] is found in the New Testament 118 times - 33 times in the Gospel of John alone (Moore 2007:155). In his farewell messages, Jesus repeatedly used the term to express the 'steadfast relationship' he enjoyed with his disciples (Carruthers 1993; Köstenberger 2004, as cited in Beisterling 2006:77-92).The idea of an older Christian coaching, developing or helping a young believer to grow, develop and mature is replete in the Bible. For example, Aquilla and Priciscilla helping Apollos to mature and develop in his preaching ministry (Ac 18:24-28). The idea of mentoring is conveyed by multiplicity of concept such as invitation for a closer relationship ('proslambanow' take, partake, receive, or accept one in house or circles [cf. Ac 27:33, 36; Rm 15:7]) exposure of a deeper truth [ekistemin'expose' - 'set forth'] in verse 26 and power of encouragement [protpethow - 'urge on', 'encourage', 'persuade'] in verse 27 [Hoehl 2011:32-47]). The cumulative impact of these semantic concepts as they relate to mentoring further communicate the quest of Aquilla and Priscilla to 'counsel, guide, and expedite' the spiritual and or career development of Appollos (Galbraith Galbraith 2001:89). A similar quest to expedite the development of Timothy and Titus is also envisaged in 1 and 2 Timothy and Titus, whereby Paul uses similar concepts to underscore his desire to expedite or help.

For the purposes of this article, mentoring is defined to develop the potential capacity and competence of these individuals in the ministry as an accommodating learning relationship between a caring individual who shares knowledge, values, attitudes, experience and wisdom with another individual. The individual must also be ready and willing to benefit from this exchange, to enrich the latter's professional and/or personal life journey. Mentoring, as can be seen from the various definitions mentioned above, could be of great value for personal development. Therefore this article will focus on the importance of mentoring as part of theological training. The context of the theological training discussed here is mainly of the denominational seminaries. Several denominational seminaries have included mentoring programs as part of their curriculums, but the actual practice of mentoring is not found on ground in most of these seminaries.

\section{Pedagogy}

Pedagogy, like mentoring, is multifaceted and not easily defined. One may add that even the definition of pedagogy appears to be somewhat difficult to understand. Pedagogy is derived from paidagogos, a Greek word meaning teacher of children. The term 'pedagogy' is being used more frequently in publications and teachers' discourse, a change that Van Manen (1993:11) attributed to an upsurge of North American interest in Western European philosophy and educational theory. Various authors have offered various definitions of pedagogy. For example, Watkins and Mortimer (1999:3) define pedagogy as 'any conscious activity by one person designed to enhance the learning of another'. Alexander (2003:3) has another definition that suggests that pedagogy requires discourse. He argues that pedagogy is the act of teaching as a discourse involving interaction with students, and not a mere monologue. Pedagogy is what one needs to know, and the skills one needs to possess in order to make and justify the many different kinds of decisions within a teaching setting. Furthermore, as an illustration, 
Leach and Moon (1999:267) expand on what may help define pedagogy by describing a pedagogical setting as 'the practice that a teacher, together with a particular group of learners, creates, enacts and experiences'. They suggest that pedagogy is a joint activity in which the learner has an active role. Hence, the term 'supportive pedagogy', for the purposes of this article, refers to an essential learning tool in the teaching and learning context that enhances positive results. This is in line with Watkins and Mortimer's (1999:3) description of pedagogy as 'any conscious activity by one person (the teacher) designed to enhance the learning of another (the learner)'. From the educational perspective, Alexander (2008:56) said that 'pedagogy' is the practice of teaching framed and informed by a shared and structured body of knowledge. This knowledge comprises experience, evidence, understanding moral purpose and shared transparent values. It is by virtue of progressively acquiring such knowledge and mastering the expertise - through initial training, continuing development, reflection and classroom inquiry and regulated practice. Educationally pedagogy has been viewed as a combination of knowledge and skills required for effective teaching (Waghid 2010:78). In other words, good pedagogy requires a broad repertoire of strategies and sustained attention to what produces student learning in a specific content domain, with a given group of students and a particular teacher.

\section{Theological education}

Similarly, the definition of theological education has also been a subject of discussion due to its changing nature. Probably the most useful definition of theological education is that of Noelliste (1995:299), who opines that theological education is the training of men and women to know and serve God in various ministry areas and which usually takes place in a college or seminary, or in a theological education programme outside the church. Sargent (2001:12) rightly notes that 'obviously, one cannot find out what theological education is by looking in the dictionary. It is what it has become in institutions organized by churches and church people to prepare men, and more recently women, for church leadership'. In the same vein, Lee (1987) offers an ideal summary of theological education when he says that:

[t]he original intention of the Bible college or seminary movement was to train men and women for Christian service in a warm spiritual environment which would nurture and deepen the faith of every student. (p. 4)

In this article, theological education is defined as the act of preparing men and women for the specialised ministries that God has called them to, within and outside the church. This article understands theological education to be more than the mere transfer of information - rather the establishment of a modelling or mentoring relationship that takes place within a theological community. The focus of the next section will be on mentoring in theological education in denominational seminaries.

\section{Mentoring as a supportive pedagogy in theological training}

Mentoring has become an increasingly important part of theological education among denominational seminaries in recent years (Daloz 2010; Crow 2008; Selzer 2008, Masango 2011). Purcell (1990:407) emphasises that the use of mentoring in theological education is an attempt to honour the complexity and the intricacy of the dynamic relationships inherent to mentoring. In the context of the teaching and learning process, mentoring has been defined as support and encouragement given to students to help them manage their own learning so that they may maximise their potential, develop their skills, improve their performance and become the person they want to be (Parsloe 2001:67). Even more important in theological training, Hillman (2006:1) defines mentoring as a partnership where the mentor takes on the responsibility of cooperating with the student in the pursuit of ministerial skills, in the development of ministerial identity, and in bringing book knowledge into dialogue with the community. Similarly, Godfrey (2005:11) defines mentoring in the teaching and learning process as an intentional process of whole-person development, facilitated by a relationship with an actively interested, more experienced, capable and helpful individual, which can be mutually beneficial, and is primarily face-to-face in its interactions.

When looking at the above definitions of mentoring in theological training, theological seminaries provide, for the most part, good opportunities for the use of mentoring as a supportive pedagogy. Banks (1999:4) observes that, whilst theological education caters for a wide audience and that the number of lay participants is increasing, so far this increase has had little impact on the content and pedagogy. Therefore the endorsement of mentorship in theological training needs to be approached with great attention and professionalism. Crow (2008:96) cites the benefits of mentoring in theological training as revealed by a survey on the retention rate of graduates from seminaries in the USA, conducted by Dr Archibald from Fuller Theological Seminary's School of Psychology. The survey revealed that for every 100 seminary graduates who went into ministry only 40 stayed in the ministry beyond five years, and a mere 20 were still in ministry ten years later. To the $20 \%$ of seminary graduates who did continue in ministry, one of the key factors contributing to their success was having a mentor while at the seminary and even after seminary training. Unfortunately the authors did not come across a research done in Africa to ascertain how pastors in full-time ministry stayed and what their reasons for staying are or were. When mentoring is used as an integral part of theological training, it serves as an important ingredient in shaping theology students. Therefore, the main focus of this article is on the role mentoring can play if used as supportive pedagogy in theological education in the three areas of spiritual, character and ministry formation. 


\section{Mentoring as a supportive pedagogy in the spiritual formation of theology students}

Mentoring as a supportive pedagogy in theological training enhances the spiritual formation of theology students. The term 'spiritual formation' is increasingly used in many different theological ministry settings to describe building depth, commitment and active faith. Ackerman (2001:12) defines spiritual formation as the act of connecting our knowledge of God with our experience of God. It is a process of transformation, of being conformed to the image of Christ by being rooted and grounded in him (Eph 3:16-21). It is a process that takes place in the inner person, whereby our character is reshaped by the Spirit, resulting in a new kind of outward activity. In the context of theological education, Greer (2001:567) defines spiritual formation as the on-going work of God's Spirit in the life of the believer in the context of the Christian community. As Christ is formed within, each Christian is equipped and empowered to fulfil God's call to ministry (diakonia), to worship (leitourgia), and to participate in community (koinonia); which builds up the whole Body of Christ. Naidoo (2005:27) points out that in those branches of Christianity where the phrase is frequently used, 'formation' is viewed as a purposeful responsibility in which those who are spiritually more mature, direct and assist the less mature.

Spiritual formation in the life of a Christian means experiencing the life of Christ being formed within the person so that there is an increasing manifestation of Christ-likeness and inner wholeness (Eph 4:22-24). The role of theological education is not only to transfer information; Strong (1999:1) states that if one of the purposes of theological education is to aid in the spiritual formation of the person who is called to ministry, the shift in education must include an intentional support system of mentors that will focus on students' spiritual formation and not merely on the dispensing of theological information.

By using mentoring as a supportive pedagogy in theological training, denominational seminaries have proven to assist theology students in their spiritual formation. Respondents in a recent survey in three ECWA seminaries (Chiroma 2012:244-246) on mentoring in theological seminaries confirmed that mentoring had played a major role in those respondents' spiritual formation, specifically in the areas of growth in their faith, trust in God, self-discovery and spiritual direction. Their mentors, who were mature Christian leaders, prayed for them and led by example as they related with their students. The respondents further attested to the fact that their mentor's modelled maturity and a whole range of other Christian qualities whilst encouraging and advising them, praying for them, listening to and directing them in the power of the Holy Spirit, supporting them and holding them accountable as growing disciples of Jesus Christ.

Babin et al. (1972:15) reminds us that there is no question about the importance of the involvement of theological educators (and therefore the seminary) in the process of helping their students towards spiritual formation. This is the very purpose of the existence of theological education. Since the very fact of being of a Christian implies becoming a mature Christian, the student is involved in a process of growth; and there is a clear obligation on the seminary, by the very nature of its theological stance, to assist in this growth process by providing mentors.

Wethmar (2000:416) argues that excellence in theological education is not so much related to how much is learned or even how well a subject is understood; rather excellence depends on how learning changes the learner holistically. In actual fact, learning takes place when there is evidence of new positive behaviour. Therefore, theological education should include not only academic excellence but it should also create room for spiritual formation through interpersonal relationships with mentors. Such relationships will enhance the integration of what students believe into their way of living - that is the application of classroom content into practice.

\section{Mentoring as a supportive pedagogy in the character formation of theology students}

Mentoring as a supportive pedagogy enhances the character formation of theology students. Moberg (2008:91-103) rightly notes that mentors in theological seminaries are in an ideal position to assist their students with character development, and since role modelling is a prominent part of the mentoring process, some character formation is almost inevitable. Cruises (2004:178) declare that as teachers in theological education ' $[w]$ e must acknowledge ... that the most important, indeed the only thing we have to offer our students is ourselves. Everything else they can read in a book'. This is because character is more caught than taught, and modelling plays an important role in character formation. Learning from role models occurs through observation and reflection, and is a complex mix of conscious and unconscious activities. Character formation grows out of a forming process that requires models to emulate. Using mentoring as a supportive pedagogy in theological training can contribute significantly to the character formation of theology students. In the survey mentioned earlier (Chiroma 2012:245), theology students highlighted several character traits they had learnt from their mentors that were helpful to them in the mentoring process while at the seminary, such as integrity, joyfulness, accountability, humility and patience.

While theological seminaries have their limitations, they can play an important role in preparing church leaders to be mature in character and to lead with integrity. English and Bowman (2001:37-52) note that it is important for students to interact with persons who are more experienced than they are in the faith and in the development of a Christian character. It is further necessary that students have an opportunity to discuss basic aspects of Christian thought and living. The use of mentoring as a supportive pedagogy in theological education can provide an opportunity to address personal development issues that, if left unresolved, could 
pose problems when it came to local church ministry. Selzer (2008:27) emphasises that through relational mentoring, theology students are prepared for what they will find in real ministry contexts.

\section{Mentoring as a supportive pedagogy in the ministry formation of theology students}

The use of mentoring as a supportive pedagogy in theological training promotes the ministry formation of students. Ministry formation is rooted in the praxis of ministry, a process of learning ministry by doing ministry. To that end, mentors provide opportunities for students to participate in various ministry experiences in different ministry contexts while at the seminary. According to Chiroma (2012:246), this process enables students to integrate their personal and professional identity and obtain academic and practical proficiency. The process also enhances the student's ability to articulate faith within real life experiences amid the changing dynamics of today's world.

Since theological training is concerned with the training of individuals for vocational ministry in various contexts, it should not only focus on imparting head knowledge, but also on developmental qualities (e.g. qualities relating to individuals' spiritual life, character and ministry). Engstrom (1989:x) warns that, if theological training does not provide the foundation for a personal contextual ministry through both instruction and mentoring, there is the possibility that students could be misled or may be ill-equipped in many areas of their various ministries. Using mentoring as a supportive pedagogy in theological training has the potential of bridging the gap between theory and practice.

Christian ministry is about servitude, and theology students will always look up to their mentors to model serving in ministry for them. Through the use of mentoring, theology students are able to gain more practical, hands-on ministry experience that will expand their ministry formation. Mentors in a theological context are able to use familiar scenarios from their ministry experience and expertise to approach ministry formation and this can increase creative thinking among theology students. It is evident that using additional relational supportive pedagogies such as mentoring is beneficial for achieving results in theological education. The next section describes how mentoring as a supportive pedagogy could be incorporated in theological training in practice.

\section{Proposed guidelines for using mentoring as a supportive pedagogy in theological training}

The aforementioned shows that the use of mentoring in theological training is not just a need but a necessity, since it could enhance the formation of theology students at a spiritual level, character-wise and with regard to their ministry. The critical question at this point is what the best practice would be for using mentoring as a supportive pedagogy in theological education for such formational processes. The following guidelines are articulated from empirical research findings Chiroma (2012:89), which indicates that even though mentoring is practiced in various denominational seminaries, there is a need for improvement and deliberate focus. Kohl (2009:152) echoes that improvement requires change and that successful leadership in ministry requires strategic formational orientation; hence we must have the courage to accept and develop new directives as we train men and women for ministry. It is unfortunate that some theological schools (denominational-based theological schools) measure success by pure academic standards, with little focus on developing spiritual, character-building and ministry experience. Kohl (2009:153) articulates that character formation, ministry formation and spiritual modelling are not always automatic outcomes of academic excellence, but rather a product of intentional mentoring. Hence, for mentoring to be a supportive pedagogy in theological education, the considerations mentioned below should be given careful thought.

Lecturers in denominational theological seminaries must see themselves as spiritual leaders. They must move beyond the notion of merely being lecturers and teachers or agents sharing information. Theological education requires lecturers to be liberated from the dichotomous concept of separating self from truth, because genuine knowledge requires personal involvement. Kohl (2009:150) opined that the personal involvement of lecturers in theological seminaries in the lives of their students creates not only genuine knowledge, but also a lasting positive impact. Payne (2010:186) challenges lecturers in theological seminaries to break away from the traditional impulse of distancing themselves from their students and from what they are teaching. He warns that effective mentoring in theological education will not occur if lecturers do not mix with students and do not show any personal passion. Theological education encompasses much more than the mere transfer of information, but rather seeks to establish a modelling and mentoring relationship that takes place within a theological community. This will only be possible if there are centralised mentoring efforts within seminaries through establishing a mentoring plan and assigning designated personnel responsible for coordinating and implementing the plan. Payne (2010:187) argues that for mentoring to be a supportive pedagogy, theological seminaries must be communities of mentors.

Lecturers in denominational seminaries must also embrace mentoring as a way of teaching. According to English and Bowman (2001:37-52), incorporating mentoring in teaching occurs when lecturers approach teaching as a spiritual discipline and bring their entire being into the teaching environment in a way that says they believe in their students. This approach sees teaching as mentoring an informal practice in which lecturers use opportunities inside and outside of classrooms to enhance the learning experience of students. Lecturers following this approach do not only teach content and skills, but also model critically reflective ministry practices (Schroeder 1993:23-29). This 
is usually done through individual coaching and ministry engagements. Even though many theological faculties are involved in various forms of mentoring, the research by Chiroma (2012:267) has indicated that many of them are not making mentoring a priority; rather the pursuit of academic excellence seems to overshadow the role of mentoring. As a result, mentoring is subtly relegated to second place and it has been left in the hands of a few volunteer lecturers and staff members. To accomplish better results in using mentoring as a supportive pedagogy in theological training, theological seminaries must make additional efforts and take measures to modify lecturer's perceptions of their roles, if not their actual job description, as it relates to student mentoring. Mentorship should be deliberately integrated into the daily routine of the student and not only at pre-set times.

For mentoring to be an effective supportive pedagogy in theological training according to research findings (Chiroma 2012; Kohl 2009) (especially within denominational seminaries), a mentor should be assigned to each student during the first semester of admittance. The mentor will establish a continuous student-mentor relationship with the student throughout his or her seminary experience. Part of the responsibilities of the mentor should be to make an initial assessment of the student's spiritual development and to assist the student to make deliberate efforts towards spiritual growth and to take responsibility for his or her spiritual development. Herring and Deininger (2002:119) advise that 'potential influence for any kind of formation in the seminary is directly related to physical proximity to students'. Thus, lecturers who reside on campus will be more accessible to students and will therefore potentially have more impact as mentors. However, one of the greatest obstacles to effective mentoring in theological education is mentors being overworked. Many of the lecturers that are involved in mentoring in theological faculties also have to prepare lectures, serve on committees and have other administrative duties, not to mention personal relationships with family, ministry work and other commitments. Despite the obstacle caused by faculty overload in mentoring, Lingenfelter and Lingenfelter (2003:57) encourage mentors by stating that there is no substitute for spending time with students in social situations in which they may feel freer to volunteer information that will inform the mentor's planning and implanting of mentoring situations. However, for this to be meaningful, several factors must be put in place considering different personalities and interests found in most mentoring relationships.

Furthermore, in order to facilitate the use of mentoring as a supportive pedagogy in theological education, there must be an on-going partnership between the church (denominations) and the (their) seminary of seminaries in all areas. Seminaries must have regular contact with the existing realities of church life. There is a clear indication that a faculty member with both church and seminary experience will not only serve as a better mentor but also be in a good position to teach from experience. There must be cooperation between the church and the seminary to explore how this can become a reality. Seminary teaching staff should be encouraged to be actively involved in a local church where they can serve in the various leadership teams. Similarly, seminaries can make use of pastors and church leaders for mentoring students at the seminary. Hence, churches (denominations) must regard their support to seminaries, especially in the area of mentoring, as one of their most important obligations.

The use of mentoring as a supportive pedagogy in theological education will require that theological seminaries provide lecturers with on-going training in mentoring principles and skills. Seminaries will need to provide comprehensive orientation and training for mentors at the start of their service as lecturers, as well as on-going training and support throughout their involvement (Stutkas \& Kanti 2005:235250). Lecturers who are expected to serve as mentors must be provided with the resources required to carry out the task of mentoring students. This would include providing resource materials and financial support to help them understand and fulfil their responsibilities as mentors. Furthermore, mentor training should equip mentors to deal with cultural differences, since diverse cultures are represented in most theological seminaries. Masango (2011:3) rightly notes that 'it is important for the mentor to know the cultural background of the mentee', since, according to Masango (2011:3), in any mentoring relationship both cultures should be understood appropriately if concerns are to be dealt with effectively and respectfully.

On the whole, the educational process for seminary students may be seen as a journey. During this journey students may benefit from interaction with mentors who have already struggled with the issues students may face in the course of their development at a spiritual level, character-wise and with regard to the development of their ministry. Strong (1999:692-712) articulates that the role of mentoring as a supportive pedagogy in theological education is rooted in how seminary lecturers see their respective roles in the formation of their students - spiritually and with regard to their character and ministry. As mentors, lecturers become guides. At the start of a particular journey they feature as helpers and equippers to their students.

Despite all the potential benefits of using mentoring as a supportive pedagogy in theological education, one must also be aware that mentoring relationships could have potential challenges. The body of literature examining challenges in mentoring relationships has grown over the years. One contributor to this argument is Harms (2007:14). He acknowledges that the experiential reports of both mentors and protégés have revealed elements of mentoring relationships that can be unproductive, unfulfilling or dysfunctional. Theological seminaries must be aware of these challenges and apply appropriate ways of dealing with them on a case-by-case basis. 
Mentoring as a supportive pedagogy in theological education among denominational seminaries becomes life in the particularity of the situations of each denomination. The uniqueness of each different educational situation calls for a specific way of mentoring which in turn yields some categories that sustain the particular actualisations of using mentoring as a supportive pedagogy. In other words, the philosophical and theological building blocks of using mentoring as a supportive pedagogy are not formulaic prescriptions or fixed methodological structures to be universally applied regardless of context or circumstances.

\section{Conclusion}

This article has argued for the use of mentoring as a supportive pedagogy in theological education, especially among denominational seminaries because of its potential for enhancing the formation of theology students at a spiritual level, character-wise and in their ministry. There is no doubt that theological education has to be relational in order to be effective in shaping students. Hence theological education can benefit from the relational nature of mentoring as a supportive pedagogy for the formation of theology students spiritually, character-wise and with regard to their ministry. This article also provided certain guidelines that will help enhance the effectiveness of mentoring as a supportive pedagogy in theological education. The positive effects of mentoring are generally thought to be derived from the support and role-modelling these relationships offer. Students learn in the classroom, of course, but they also can learn a great deal in less formal settings from lecturers and other mentors.

\section{Acknowledgements Competing interests}

The authors declare that they have no financial or personal relationship(s) that may have inappropriately influenced then in writing this article.

\section{Authors' contributions}

N.H.C. (Stellenbosch University) undertook to compile the article and also contributed intellectually to the writing of the article. A.C. (Stellenbosch University) supervised and provided intellectual contributions throughout the writing of the article.

\section{References}

Addington, J. \& Graves, L., 2010, 'Enriching mentoring relationships', The Personnel and Guidance Journal 62, 329-332.

Ackerman, J., 2001, Listening to God: spiritual formation in congregations, Alban Institute, Herndon.

Alexander, H., 2003, Mentoring for social inclusion: A critical approach to nurturing mentor relationships, Routledge Falmer, Abingdon.

Alexander, R.J., 2008, Essays on pedagogy, Routledge, London.

Babin, D.E., Briner, L.A, Hoon, P.W., Martin, W.R., Smith, T., Van Antwerp, E.I. et al., 1972, 'Voyage, vision, venture: A report', American Association of Theological Schools, Dayton.
Banks, R., 1999, Re-envisioning theological education: exploring missional alternatives to current models, Eerdmans, Grand Rapids.

Beisterling, R., 2006, 'The mentoring approach of Jesus as demonstrated in John 13', Journal of Youth Ministry 5(1), 77-92.

Carruthers, J., 1993, 'The principles and practices of mentoring', in B.J. Caldwell \& E.M. Carter (eds.), The return of the mentor, Falmer Press, London.

Chiroma, N., 2012, 'Critical evaluation of mentoring programs in theological seminaries of the Evangelical Church of West Africa (ECWA)', Unpublished PhD dissertation, Stellenbosch University, Stellenbosch.

Collins, C., 2009, 'A method for encouraging the development of good mentor-protégé relationships', Teaching of Psychology, 16, 80-128.

Cove, M., McAdam, J. \& McGonigal, J., 2007, 'Mentoring in the North: new provision, new perspectives?', Education in the North 15(1), 87.

Cruises, W., 2004, Theological schools that work, Dutton, New York.

Crow, G.M., 2008, Doing mentoring the Jesus way, University of North Carolina Press, Chapel Hill.

Daloz, L.A. 2010. An examination of effective mentoring models in academe, Jossey Bass: Wiley, Hoboken.

Delamarter, S., Alanís, J., Haitch, R., Hoffman, M.V., Jones, A.W., \& Strawn, B.A., 2007, 'Technology, pedagogy, and transformation in theological education: Five cases', Teaching theology and religion 10(2). http://dx.doi.org/10.1111/j.14679647.2007.00319.x

English, L. \& Bowman, L., 2001, 'Working with experience: the mentor, the context, the possibility', British Journal of Theological Education 12(1), 37-52. http:// dx.doi.org/10.1558/jate.v12i1.37

Engstrom, T.W., 1989, The fine art of mentoring: passing on to others what God has given to you, Wolgemuth \& Hyatt Publishers, Brentwood.

Farley, E. 2005, 'Four pedagogical mistakes: A mea culpa', Teaching Theology Religion 8(4), 200-203. http://dx.doi.org/10.1111/j.1467-9647.2005.00246.x

Faure, A., 2000, 'Gifts of mentorships', Gifted Child Quarterly 29, 20-45.

Galbraith, M.W., 2001, Gender and the mentoring process, Jossey-Bass, San Francisco.

Greer, R., 2001, Christian hope and Christian life: raids on the inarticulate, Crossroad, New York.

Godfrey, D., 2005, Mentoring manager: Strategies for fostering talent and spreading knowledge, Pearson Education, London.

Harms, J., 2007, Mentoring. A Henley review of best practice, Palgrave MacMillan, New York.

Herring, R. \& Deininger, F., 2002, 'The challenges and blessings of spiritual formation in theological education', in M.W. Kohl \& A.N. LalSenanayake (eds.), Educating for tomorrow: Theological leadership for the Asian context, pp. 113-126, SAIACS Press, Kothanur.

Hillman, J., 2006, 'Mentoring and the faculty development of African-American doctoral students', in H.T. Jr. Frierson (ed.), Diversity in higher education, pp. 1-39, JAI, Greenwich.

Hoehl, S., 2011, 'The mentoring relationship: An exploration of Paul as loving mentor to Timothy and the application of this relationship to contemporary leadership challenges', Journal of Biblical Perspectives in Leadership 3(2), 32-47.

Klasen, K., \& Clutterbuck, D., 2002, Implementing mentoring schemes: A practical guide to successful programmes, Elsevier Butterworth-Heinemann, Oxford.

Kohl, M., 2009, 'Theological education: what needs to be changed', TTJ 12(1), 149-162.

Kostenberger, A.J., 2004, Baker Exegetical Commentary on the New Testament, John, Baker Academic, Grand Rapids.

Kram, K.E., 1985, Mentoring at work: Developmental relationships in organizational life, Scott, Foresman, Glenview.

Leach, J. and Moon, B., 1999, 'Recreating pedagogy', in J. Leach \& B. Moon (eds.) Learners and pedagogy, Paul Chapman, London.

Lee, D., 1987, Towards a definition of theological education, Eerdmans, Grand Rapids.

Lingenfelter, J.E. \& Lingenfelter, S.G., 2003, Teaching cross-culturally, an incarnational model for learning and teaching, Baker Academic, Grand Rapids.

Masango, M., 2011, 'Mentorship: a process of nurturing others', HTS Teologiese Studies/Theological Studies 67(1), Art \# 937, 5 pages.

Merriam, S., 1983, 'Mentor and protégés: a critical review of the literature', Adult Education Quarterly 33, 161-173.

Moberg, D.J., 2008, 'Mentoring for protégé character development', Mentoring \& Tutoring: Partnership in Learning 16(1), 91-103. http://dx.doi.org/10.1080/ 13611260701801056

Moore, T., 2007, Care of the soul, Harper-Collins, New York.

Naidoo, M., 2005, 'An investigation into spiritual formation programmes at selected theological institutions in KwaZulu-Natal', Unpublished D.Th. thesis, University of Zululand, Richards Bay.

Noelliste, D., 1995, 'Towards a theology of theological education', Evangelical Review of Theology 19(3).

Ospino, H. 2010. 'Theological Horizons for a Pedagogy of Accompaniment'. Religious Education: The official journal of the Religious Education Association 105(4), 413-429. 
Parsloe, E., 2001, Coaching, mentoring and assessing: A practical guide to developing competence, Kogan Page, London.

Payne, I., 2010, 'Theological reflection methods', In Harkness, A. (ed.), Tending the seedbeds: Educational perspectives on theological education in Asia, pp. 167-191, Manila Asia Theological Association, Manila.

Philip, K., 2000, 'Mentoring pitfalls and potential for young people', Youth and Policy 67, 1-15.

Purcell, M.F., 1990, 'Mentoring', in Harper's Encyclopedia of religious education, pp. 407-408, Harper \& Row, San Francisco.

Sargent, T., 2001, 'The value of theological education for ministry and service', An address given to the Baptist Union Assembly, Scotland, 24 October. (Unpublished).

Schroeder, D.E., 1993, 'Faculty as mentors: some leading thought for re-evaluating our role as Christian educators', Christian Education Journal 13(2), 23-29.
Selzer, E.H., 2008, 'Effectiveness of seminary's training and mentoring program and subsequent job satisfaction of its graduates', Journal of Research on Christian Education 17, 25-53. http://dx.doi.org/10.1080/10656210801967309

Strong, L., 1999, 'Role models, mentors, and sponsors in theological seminaries', Signs $6(4), 692-712$

Stutkas, M. \& Kanti, J., 2005, 'Mentoring mobilizations', Journal of Youth Studies 7, 235-250

Van Manen, M., 1993, The tact of teaching: The pedagogical meaning of thoughtfulness, The Althouse Press, Ontario.

Waghid, Y., 2010, Education democracy and citizenship revisited: pedagogical encounters, SUN Press, Stellenbosch.

Watkins, C. \& Mortimer, D., 1999, Teaching and learning, Sage, London.

Wethmar, C.J., 2000, 'Theological education in an ecumenical context: principles and procedures of the Pretoria model', Skrif en Kerk 21(2), 416-428. 